\title{
The Aromatic Plant Satureja horvatii ssp. macrophylla Induces Apoptosis and Cell Death to the A549 Cancer Cell Line
}

\author{
Paraskevi Yfanti' ${ }^{1}$ Anna Batistatou ${ }^{2}$, Georgios Manos' ${ }^{1}$, Marilena E. Lekka ${ }^{3 *}$ \\ ${ }^{1}$ Department of Agricultural Technology, Technological Education Institute of Epirus, Arta, Greece \\ ${ }^{2}$ Medical School, University of Ioannina, Ioannina, Greece \\ ${ }^{3}$ Chemistry Department, University of Ioannina, Ioannina, Greece \\ Email: ${ }^{*}$ mlekka@uoi.gr
}

Received 17 June 2015; accepted 21 August 2015; published 27 August 2015

Copyright (C) 2015 by authors and Scientific Research Publishing Inc.

This work is licensed under the Creative Commons Attribution International License (CC BY).

http://creativecommons.org/licenses/by/4.0/

c) (i) Open Access

\begin{abstract}
S. horvatii ssp. macrophylla (Lamiaceae) is an endemic aromatic plant of Greece and is used as a culinary herb. In the present study we explored its possible anticancer activity through the induction of apoptosis on cancer cells using A549 cell line as a model. The cytotoxic effects and the type of cell death (apoptosis/necrosis) were evaluated with biochemical and morphological criteria. The total methanol extract of $S$. horvatii ssp. macrophylla revealed forty two components, of which carvacrol was the major constituent $(43.2 \%)$. Only a minor portion of them $(3.41 \%)$ was contained in the active working plant extract solution which was used for cell treatment. This study indicates that extract of $S$. horvatii spp. macrophylla, which belongs to carvacrol chemotype, can induce both apoptosis and necrosis to A549 cancer cell line.
\end{abstract}

\section{Keywords}

Satureja horvatii spp. macrophylla, Apoptosis, Cytotoxicity, A549, GC/MS

\section{Introduction}

Aromatic plants that are used as spices to improve food flavor possess beneficial properties on human health. Some of these plants, known since ancient times, are characterized as medicinal plants, with bioactive secondary metabolites. S. horvatii ssp. macrophylla, a member of Satureja montana aggregate, is a perennial low shrub belonging to the Lamiaceae family. It is an endemic aromatic plant restricted to the region of NW Greece [1]. In

*Corresponding author.

How to cite this paper: Yfanti, P., Batistatou, A., Manos, G. and Lekka, M.E. (2015) The Aromatic Plant Satureja horvatii ssp. macrophylla Induces Apoptosis and Cell Death to the A549 Cancer Cell Line. American Journal of Plant Sciences, 6, 20922103. http://dx.doi.org/10.4236/ajps.2015.613210 
traditional (folk) medicine boiled plant leafs have been used, until today, mixed with other species, as decoction, also for traditional treatment of bronchitis. It is used as a culinary herb and it is also known as an important honey plant.

Secondary metabolites of Satureja species, such as essential oils, phenolic compounds, flavonoids, are known for their healing properties and some of them have been used as traditional medicinal plants. Plant extracts or essential oils from various species of Satureja have been shown to encompass several biological activities, like antimicrobial [2], antiviral [3], antioxidant [4]-[8], antiinflammatory [9] and antiproliferative effect on human tumor cell lines [10]. Studies on the biological properties of S. horvatii ssp. macrophylla have not been published.

According to recent studies, wild species in the Mediterranean basin, belonging to the family of Lamiaceae, have shown cytotoxic effects on human cancer cell lines [11]-[15]. It has been found that some of them like Origanum vulgare [16], Origanum majorana [17], Salvia fruticosa, Salvia officinalis [18] and Melissa officinalis [19] induce apoptosis on the tested cancer cell lines. Apoptosis is the programmed cell death and plays a crucial role in cell turnover, as well as in the elimination of injured or malignant cells. Apoptosis can be activated through external pathways, involving receptors of the cell membrane, or through internal pathways, involving mitochondrial proteins. Synthetic chemicals or compounds isolated from natural sources that induce apoptosis can be investigated as possible anti-cancer compounds, especially those that do not affect normal cells.

The aim of the present study was to investigate whether $S$. horvatii ssp. macrophylla can induce cell death on A549 human bronchial epithelial adenocarcinoma cell line, as well as the type of cell death (apoptosis-necrosis) and to investigate the ingredients of the biologically active extract.

\section{Material and Methods}

\subsection{Plant Material}

The plant material was collected from wild grown populations, at the flowering stage, in September 2010, on mount Olimbusion, municipality Ziros, Epirus, Greece at $800 \mathrm{~m}$ altitude. The aerial plant material was first freezed at $-20^{\circ} \mathrm{C}$ and then lyophilized with a freeze-dryer (ALPHA 1-2/LD plus, Martin Christ Gmbh, Germany). Voucher specimens are kept at the herbarium of the Technological Educational Institute of Epirus.

\subsection{Preparation of Total Methanol Extract}

The freeze-dried plant material was pulverized to less than $0.2 \mathrm{~mm}$ particles, using a mix and mille equipment (Polymix, Kinematica, USA). Then, it was extracted with methanol (1:10, w/v) by sonication using ultrasound bath Sonorex (Badelin electronic, Germany) for $3 \times 10 \mathrm{~min}$. The temperature of the bath was kept under $40^{\circ} \mathrm{C}$. After the extraction the samples were centrifuged (Sigma 2 - 5) at $4.250 \mathrm{rpm}$ for $10 \mathrm{~min}$ and filtered through Whatman paper No. 1 . The extract was then aliquoted and stored at $-20^{\circ} \mathrm{C}$ until the analysis.

\subsection{Preparation of the Working Plant Extract Solution}

The working plant extract solution (WPES), which was used for cell treatment in dose- and time-dependent experiments, comprised the aqueous-soluble compounds of the total methanol extract after drying at $40^{\circ} \mathrm{C}$. Briefly, portions from the stock $\mathrm{MeOH}$ extract of the freeze-dried aromatic plant were dried under nitrogen stream at $40^{\circ} \mathrm{C}$ and were re-dissolved into the appropriate volume of the serum-free cell medium to achieve final concentrations of $2-4-6-10-20 \mathrm{mg} \cdot \mathrm{dw} \cdot \mathrm{mL}^{-1}$. The solutions were centrifuged at $1500 \times \mathrm{g}$ for $15 \mathrm{~min}$ before applying to the cells, and the precipitate was discarded. All the experiments were performed into 3 biological replicas with two technical replicas each.

\subsection{Cell Culture}

Human bronchial adenocarcinoma cell line A549 was used as model of cancer cells. The cells were cultured in Ham's F-12K medium (Gibco), containing 10\% heat-inactivated fetal bovin serum (FBS) (Gibco), $2 \mathrm{mM} \cdot \mathrm{L}$ glutamine (Seromed), $1.5 \mathrm{~g} \cdot \mathrm{L}^{-1}$ Sodium bicarbonate (Gibco), $100 \mathrm{u} / \mathrm{mL}$ penicillin $\mathrm{G}, 100 \mathrm{u} / \mathrm{mL}$ streptomycin sulfate and $0.25 \mu \mathrm{g} / \mathrm{L}$ amphotericin B (Antibiotic-antimycotic, Gibco). The cells were cultured on $90 \mathrm{~mm}$ petri dishes in a $5 \%(\mathrm{v} / \mathrm{v}) \mathrm{CO}_{2}$ incubator, at $37^{\circ} \mathrm{C}$. Before reaching confluence, the medium was removed by aspiration; the ad- 
herent cells were washed with phosphate buffered saline (PBS) and detached by incubation with trypsin-EDTA. After trypsin inactivation with PBS the cells were isolated by centrifugation at $800 \times \mathrm{g}$ for $5 \mathrm{~min}$, the supernatant was discarded, and the pellet was resuspended into $1 \mathrm{~mL}$ of complete medium and kept in aliquots at $-80^{\circ} \mathrm{C}$ until use.

\subsection{Flow Cytometric Analysis}

Cell viability was determined by trypan blue exclusion assay. Then A549 cells were seeded at a density of $1 \times$ $10^{6}$ cells on 55-mm culture dishes, preincubated for $24 \mathrm{~h}$ and finally incubated with the selected concentrations of plant extracts in serum free medium for another $24 \mathrm{~h}$. After incubation the cells were observed with an inverted microscope (A. Krüss optronic, Germany) equipped with a digital camera (Nikon coolpix 4500) and collected by trypsinization after washing twice with cold PBS followed by centrifugation at $1000 \times \mathrm{g}$ for $5 \mathrm{~min}$. The pellet was resuspended into $1 \mathrm{~mL}$ binding buffer solution $\left(1: 9\right.$ in PBS) $\left(10^{6}\right.$ cells $\left.\cdot \mathrm{mL}^{-1}\right)$. Portions $(100 \mu \mathrm{L})$ of the sample solution were transferred to a $5-\mathrm{mL}$ tube (Becton Dickinson) and incubated with $5 \mu \mathrm{L}$ of annexin-V FITC (Pharmingen) and $5 \mu \mathrm{L}$ of PI for $15 \mathrm{~min}$ at room temperature in the dark. Binding buffer solution was added to each sample tube. Cells were next analyzed by a FACS flow cytometry (Becton Dickinson) using Cell Quest Research Software. Blank samples of cells, without treatment with the working aqueous plant extracts, were used as controls.

\subsection{Cell Staining}

The effect of $S$. horvatii ssp. macrophylla methanol extract on cell morphology was studied in dose-(10 $\left.\mathrm{mg} \cdot \mathrm{mL}^{-1}, 20 \mathrm{mg} \cdot \mathrm{mL}^{-1}\right)$ and time-(3, 6, 24, $\left.48 \mathrm{~h}\right)$ dependent experiments. After treatment, the cells were collected by trypsinization, washed with cold PBS and centrifuged at $1100 \times \mathrm{g}$ for $5 \mathrm{~min}$. The supernatant was discarded, the cell pellet was spread on a microscopic glass slide and the smear was allowed to dry in air.

For haematoxylin-eosin staining, the slides were immersed into 96\% EtOH for $1 \mathrm{sec}$, rinsed with water, immersed in haematoxylin solution for $1.5 \mathrm{sec}$, rinsed again with water, placed in Eosin solution and washed twice consequently with EtOH 96\%, acetone and xylol. The cover slip was mounted on the slide with DPX mountant (Atom scientific, UK). Cells were observed using Nikon eclipse 50i, light microscope and photographed with an adapted digital camera.

For Dapi staining the slides were placed in 3.7\% paraformaldehyde for 10 min, washed for 3 times with PBS, stained with DAPI staining solution (4',6-diamidino-2-phenylindole, $0.04 \mu \mathrm{g} \cdot \mathrm{mL}^{-1} \mathrm{PBS}$ ) for $5 \mathrm{~min}$ in the dark and washed for three times with PBS. Cells were covered with antifade (p-phenylenediamine, Sigma) (0.1 $\mu \mathrm{g} \cdot \mathrm{mL}^{-1} 90 \%$ glycerol-1xPBS), sealed with a coverslip and observed using a fluorescent microscopy (Eclipse E400, Nikon) equipped with an ultraviolet illumination. Nuclear condensation and segmentation were examined with fluorescent microscopy (Eclipse E400, Nikon) equipped with an ultraviolet illumination and photographed with an adapted digital camera.

\subsection{Western Blot Analysis}

After treatment with 10 or $20 \mathrm{mg} \cdot \mathrm{dw} \cdot \mathrm{mL}^{-1}$ of $S$. horvatii ssp. macrophylla for 24 and 48 hours, the cells, $(1 \times$ $10^{6}$ per plate) were harvested by a cell scraper, centrifuged at $1500 \times \mathrm{g}$ for $10 \mathrm{~min}$ and washed twice with cold PBS. The cell pellet was resuspended in $400 \mu \mathrm{L}$ PBS and homogenized by sonication $(3 \times 10 \mathrm{sec})$. SDS-PAGE electrophoresis was performed on $4 \mu \mathrm{g}$ total protein from each cell homogenate, using $12 \%$ polyacrylamide gel. Electrophoresis was run at $150 \mathrm{~V}$, followed by electrical transferred of the bands to a methanol activated polyvinylidene difluoride (PVDF) membrane at $150 \mathrm{~mA}$ for $2 \mathrm{~h}$, using a shemi-dry transfer unit (Hoefer TE 7O, Amersham Bioscience). The blots were incubated overnight with non-fat dried milk $5 \%$ in blocking solution (Tris-buffered saline containing $0.1 \%$ Tween 20 ) at $4^{\circ} \mathrm{C}$. After washing (blocking solution $3 \times 10 \mathrm{~min}$ ) the membranes were incubated with a selected primary antibody diluted in blocking solution. Antibodies used were caspase-3 (Santa Cruz, Biotechnology, CA, USA) and $\beta$-actin (Santa Cruz, Biotechnology, CA, USA) at dilution 1:500. After 4 hours incubation at $4^{\circ} \mathrm{C}$, the primary antibody was washed away and a secondary antibody was applied for $2 \mathrm{~h}$. Anti-mouse IgG antibody was used us secondary antibody at dilution 1:10.000. Antibody binding was detected using the ECL detection system (Amersham Biosciences). The membrane was then exposed to a film. 


\subsection{GC/MS, DHS/GC/MS Analysis}

Total MeOH extract and the working plant extract solution were analyzed by GC/MS: Briefly, the total MeOH extract was filtered through a $0.45 \mu \mathrm{m}$ filter and analyzed by GC/MS directly. To investigate the nature of the ingredients recovered into the working plant extract solution, a 2-mL portion from the filtered methanol extract was transferred to a test tube, dried under nitrogen flow at $40^{\circ} \mathrm{C}$ and it was re-dissolved into $10 \mathrm{~mL} \mathrm{dd} \mathrm{H}_{2} \mathrm{O}(20$ $\mathrm{mg} \cdot \mathrm{dw} \cdot \mathrm{mL}^{-1}$ ). To imitate the experimental conditions followed for cell treatment, the water solution was then freeze-dried and re-dissolved into $2 \mathrm{~mL}$ methanol for GC/MS analysis.

The GC/MS system, (Master GC, Fast chromatograph, Dani) coupled with a Time-of-flight mass spectrometry, TOF MS, Dani), was equipped with a capillary column BPX-5 (30 m × $0.25 \mathrm{~mm} \times$ film thickness $0.25 \mu \mathrm{m})$ and autosampler (Master AS, Dani). Carrier gas was Helium (He) at a flow rate of $0.7 \mathrm{~mL} \cdot \mathrm{min}^{-1}$ and split ratio 1:30. Injector and MS transfer line temperatures were set at $250^{\circ} \mathrm{C}$ and $280^{\circ} \mathrm{C}$, respectively. Oven temperature programme was the following: $60^{\circ} \mathrm{C}$ to $110^{\circ} \mathrm{C}$ at $3^{\circ} \mathrm{C} \cdot \mathrm{min}^{-1}, 110^{\circ} \mathrm{C}$ isothermal for $10 \mathrm{~min}, 110^{\circ} \mathrm{C}$ to $150^{\circ} \mathrm{C}$ at $3^{\circ} \mathrm{C} \cdot \mathrm{min}^{-1}, 150^{\circ} \mathrm{C}$ to $280^{\circ} \mathrm{C}$ at $30^{\circ} \mathrm{C} \cdot \mathrm{min}^{-1}, 280^{\circ} \mathrm{C}$ isothermal for $5 \mathrm{~min}$. The MS operating parameters were as follows: ionization potential $70 \mathrm{eV}$, ion source temperature $200^{\circ} \mathrm{C}$, acquisition rate: 5 spectra s${ }^{-1}$, spectral range: from 50 to $550 \mathrm{~m} / \mathrm{z}$, injection volume: $1.0 \mu \mathrm{L}$.

The volatile compounds of the initial pulverized plant samples were analyzed by DHS/GC/MS. Briefly, 10 mg from each sample was mixed with $1 \mathrm{~mL}$ of deionized water in a 20-mL head space vial, sealed with silicon septum and an aluminum cap and was placed in the DHS autosampler. The analytical conditions of DHS were: Incubation time $15 \mathrm{~min}$, oven temperature $40^{\circ} \mathrm{C}$, stripping time $5 \mathrm{~min}$, He stripping flow $60 \mathrm{~mL} \cdot \mathrm{min}^{-1}$, trap temperature $35^{\circ} \mathrm{C}$, trap Temp $250^{\circ} \mathrm{C}$ (thermal desorbsion), dew stop temp $0^{\circ} \mathrm{C}$, injection 1 min, transfer line $280^{\circ} \mathrm{C}$.

The components were indentified on the basis of their relative retention times and their mass spectra, using Nist library data (MS search 2.0) and data from the literature. The results were also confirmed by the comparison of the compound elution orders with their Kovats indices.

\section{Results}

\subsection{GC/MS Analysis}

The total methanol extract of $S$. horvatii ssp. macrophylla, the volatiles fraction and the working plant extract solution used for cell treatment were analyzed by GC/MS techniques. The percentage of the indentified constituents is summarized in Table 1 in the order of their elution times. According to GC/MS analysis, forty two components were indentified in the total methanol extract, representing the $96.0 \%$ of the total compounds appearing in the chromatogram. Oxygenated monoterpenes comprised a large portion (55.63\%), among which carvacrol (43.2\% of total) was the major constituent. Thymol, the other phenolic monoterpene, was present in minor quantities (2.01\%). Monoterpenic hydrocarbons covered the $35.1 \%$. The main components of this fraction were $p$-cymene (21.98\%) and $\gamma$-terpinene (7.79\%), representing biosynthetic precursors of the monoterpenic phenols. We also detected the oxygenated monoterpenic hydrocarbons borneol (3.8\%) and thymoquinone (2.93\%). Sesquiterpenes (6.45\%) comprised a small part of the volatile fraction, in which caryophyllene (3.75\%) was a major constituent.

GC/MS analysis of the working plant extract solution (WPES) showed only 12 out of the 42 constituents found in the total $\mathrm{MeOH}$ extract. These 12 constituents comprised the $3.41 \%$ of the ingredients identified in the total methanol extract, with major representatives the oxygenated monoterpenes carvacrol, thymoquinone and borneol. Sesquiterpenes were not detected in this fraction. The results are shown in Table 1, where each substance was expressed: 1 ) as percentage of the sum area of the 12 identified compounds in the working plant extract solution and 2) as percentage of the sum of the ingredients identified in WPES.

Finally, to identify the nature of the volatiles fraction of $S$. horvatii ssp. macrophylla plant material, we performed analysis by DHS/GC/MS. As shown in Table 1, the analysis revealed the presence of monoterpenic hydrocarbons as well the oxygenated monoterpenes 1,8-cineol, trans-sabinene hydrate, linalool, and thymol methyl ether. These compounds were also present in the total methanol extract, as confirmed by GC/MS. Differences between the composition of volatiles, total methanol extract and working plant extract solution were observed, whereas certain compounds were either totally missing, or some of them ( $p$-cymene, $\gamma$-terpinene, trans-sabinene hydrate and linalool) were partially recovered in minor quantities. 
Table 1. Analysis of S. horvatii ssp. macrophylla extract fractions.

\begin{tabular}{|c|c|c|c|c|c|c|c|}
\hline \multirow[b]{2}{*}{$\mathbf{A} / \mathbf{A}$} & \multicolumn{2}{|c|}{$\begin{array}{l}\text { RETENTION } \\
\text { TIMES }\end{array}$} & \multirow[b]{2}{*}{ RI } & \multirow[b]{2}{*}{ COMPONENTS } & \multicolumn{3}{|c|}{ COMPOSITION (\%) } \\
\hline & GC-MS & $\begin{array}{l}\text { DHS-G } \\
\text { C-MS }\end{array}$ & & & $\begin{array}{c}\text { A. } \\
\text { MeOH } \\
\text { Extract }\end{array}$ & B. WPES & $\begin{array}{l}\text { C. Volatiles } \\
\text { Fraction }\end{array}$ \\
\hline 1. & 6.00 & 6.31 & 928 & $\alpha$-Thujene & 0.90 & - & 5.24 \\
\hline 2. & 6.24 & 6.55 & 937 & $\alpha$-Pinene & 0.95 & - & 5.25 \\
\hline 3. & 6.78 & 7.07 & 955 & Camphene & 1.22 & - & 5.47 \\
\hline 4. & - & 7.73 & 977 & Sabinene & - & - & 0.11 \\
\hline 5. & - & 7.92 & 984 & $\beta$-Pinene & - & - & 1.19 \\
\hline 6. & 7.69 & - & 986 & 1-Octen-3-ol & 1.42 & 0.75 & - \\
\hline 7. & 7.90 & 8.16 & 993 & $\alpha$-Myrcene & 1.12 & - & 7.26 \\
\hline 8. & 8.23 & - & 1004 & 3-Octanol & 0.07 & - & - \\
\hline 9. & 8.59 & 8.87 & 1013 \& 1014 & $\alpha$-Phellandrene $+\delta 3$-Carene & 0.15 & - & 1.19 \\
\hline 10. & 8.95 & 9.21 & 1023 & $\alpha$-Terpinene & 0.50 & - & - \\
\hline 11. & 9.29 & $9.57 *$ & 1033 & p-Cymene & 21.98 & 0.88 & $39.65^{*}$ \\
\hline 12. & 9.40 & & 1035 & Limonene & 0.43 & - & - \\
\hline 13. & 9.55 & 9.80 & 1039 & 1,8-Cineole & 1.03 & - & 5.23 \\
\hline 14. & 9.95 & - & 1049 & cis-Ocimene & 0.02 & - & - \\
\hline 15. & 10.49 & 10.75 & 1065 & $\gamma$-Terpinene & 7.79 & 0.23 & 22.02 \\
\hline 16. & 11.03 & 11.41 & 1080 & trans Sabinene hydrate & 1.11 & 0.54 & 0.03 \\
\hline 17. & 11.55 & 11.81 & 1093 & Terpinolene & 0.04 & - & 0.05 \\
\hline 18. & 12.14 & 12.47 & 1107 & Linalool & 0.87 & 0.55 & 0.09 \\
\hline 19. & 14.04 & - & 1153 & trans-Pinocarveol & 0.03 & - & - \\
\hline 20. & 14.23 & - & 1157 & cis-Verbenol & 0.04 & - & - \\
\hline 21. & 14.40 & - & 1161 & Camphor & 0.05 & - & - \\
\hline 22. & 15.40 & - & 1185 & Borneol & 3.8 & 4.87 & - \\
\hline 23. & 15.71 & - & 1192 & Terpinene-4-ol & 0.32 & 0.6 & - \\
\hline 24. & 16.11 & - & 1201 & p-Cymen-8-ol & 0.09 & 0.47 & - \\
\hline 25. & 16.40 & - & 1207 & $\alpha$-Terpineol & 0.10 & 0.45 & - \\
\hline 26. & 16.60 & - & 1211 & Dihydrocarvone & 0.05 & - & - \\
\hline 27. & 18.24 & 18.48 & 1242 & Thymol methyl ether & 1.33 & - & 2.17 \\
\hline 28. & 19.21 & - & 1261 & Thymoquinone & 2.93 & 4.86 & - \\
\hline 29. & 21.58 & - & 1304 & Thymol & 2.01 & 1.82 & - \\
\hline 30. & 22.20 & - & 1313 & Carvacrol & 43.2 & 83.99 & - \\
\hline 31. & 31.15 & - & 1424 & Caryophyllene & 3.75 & - & - \\
\hline 32. & 32.49 & - & 1444 & Aromadendrene & 0.22 & - & - \\
\hline 33. & 33.63 & - & 1461 & $\alpha$-Humulene & 0.15 & - & - \\
\hline 34. & 33.91 & - & 1465 & Alloaromadendrene & 0.04 & - & - \\
\hline 35. & 35.27 & - & 1480 & $\gamma$-Muurolene & 0.05 & - & - \\
\hline 36. & 35.85 & - & 1494 & Viridiflorene & 0.05 & - & - \\
\hline
\end{tabular}




\begin{tabular}{|c|c|c|c|c|c|c|c|}
\hline Contin & & & & & & & \\
\hline 37. & 36.14 & - & 1498 & $\gamma$-Elemene & 0.13 & - & - \\
\hline 38. & 36.89 & - & 1514 & b-Bisabolene & 0.93 & - & - \\
\hline 39. & 37.18 & - & 1520 & $\gamma$-Cadinene & 0.04 & - & - \\
\hline 40. & 37.45 & - & 1526 & $\delta$-Cadinene & 0.06 & - & - \\
\hline 41. & 40.52 & - & 1591 & (-)-Spathulenol & 0.22 & - & - \\
\hline 42. & 40.64 & - & 1594 & Caryophyllene oxide & 0.79 & - & - \\
\hline 43. & 40.76 & - & 1596 & Viridiflorol & 0.02 & - & - \\
\hline Total & & & & & 100 & 100 & 100 \\
\hline Monot & ne hydro & & & & 35.1 & 1.11 & 92.49 \\
\hline Oxyger & monote & & & & 55.63 & 98.15 & 5.35 \\
\hline Sesquit & ne hydr & & & & 5.44 & & \\
\hline Oxyger & sesquit & & & & 1.01 & & \\
\hline Others & & & & & 2.82 & 0.75 & 2.17 \\
\hline Monot & & & & & 90.73 & 99.26 & \\
\hline Sesquit & nes & & & & 6.45 & 0.75 & \\
\hline
\end{tabular}

${ }^{*}$ p-Cymene + Limonene.

\subsection{Cytotoxic Effect of $S$. horvatii ssp. macrophylla on A549 Cancer Cell Line}

The pro-apoptotic and cytotoxic effects of the working plant extract solution on A549 cells were studied by flow cytometry. Figure 1 shows a typical pattern of the analysis of doubly-stained cells with Annexin V- FITC/PI. We distinguished among I) early apoptosis (Annexin V positive, PI negative), II) late apoptosis (Annexin V positive, PI positive), III) necrosis (Annexin V negative, PI negative), and IV) viable cells (Annexin V negative, PI negative), in the total cell population. Cell death was calculated from the sum of early, late apoptotic and necrotic cells' percentages.

As shown in Figure 2, for extracts corresponding to concentrations 2 and $4 \mathrm{mg}$ dry plant material $\mathrm{mL}^{-1}$ we did not observe any significant difference in total cell death in comparison with the control (Bonferroni test $\mathrm{p}=$ 1.00). However, at the concentration of $10 \mathrm{mg} \cdot \mathrm{mL}^{-1}$, the percentage on total cell death was dramatically increased $(73.37 \% \pm 4.24 \%)$ (Anova $\mathrm{p}=0.000)$, comprising both early $(18.86 \% \pm 0.91 \%)$ and late apoptosis $(51.97 \% \pm 4.17 \%)$, while the percentage of necrosis was low $(2.53 \% \pm 0.83 \%)$. Finally, at the concentration of $20 \mathrm{mg} \cdot \mathrm{mL}^{-1}$, although the percentage of necrosis increased significantly to $11.88 \% \pm 3.55 \%$, in comparison with cells treated with $10 \mathrm{mg} \cdot \mathrm{mL}^{-1},(\mathrm{p}=0.004)$, the total cell death significantly declined. This was due to a significant decrease in the percentages of early $(13.76 \% \pm 1.44 \%)$ and late apoptosis $(31.89 \% \pm 9.51 \%)$ (Bonferroni test $\mathrm{p}=0.001$ and $\mathrm{p}=0.026$, respectively).

It is noteworthy that after $24 \mathrm{~h}$ incubation of the cells with $10 \mathrm{mg} \cdot \mathrm{mL}^{-1}$, the flow cytometer could not measure efficiently, presenting low level of events. This phenomenon was not observed for the other concentrations, including $20 \mathrm{mg} \cdot \mathrm{mL}^{-1}$.

\subsection{Effect of S. horvatii ssp. macrophylla on Cell Morphology}

Twenty-four hours after incubation with the different concentrations, the cells were examined by phase contrast microscopy (Figure 3). The control cells and those treated with the lower concentrations of S. horvatii ssp. macrophylla (2 mg. $\mathrm{mL}^{-1}, 4 \mathrm{mg} \cdot \mathrm{mL}^{-1}$ ) showed a typical polygonal shape and overall intact appearance. However, cells treated with higher concentrations, $\left(10\right.$ and $\left.20 \mathrm{mg} \cdot \mathrm{mL}^{-1}\right)$ displayed morphological changes, such as cellular shrinkage, poor adherence and cell detachment or swelling with round shape.

Untreated and treated A549 cells with different concentrations $\left(10 \mathrm{mg} \cdot \mathrm{mL}^{-1}, 20 \mathrm{mg} \cdot \mathrm{mL}^{-1}\right)$ and for different incubation times (3, 6, 24, 48 h) were examined after haematoxylin-eosin staining by light microscopy for morphological changes. As shown in Figure 4, untreated cells presented a normal morphology, whereas treated cells 


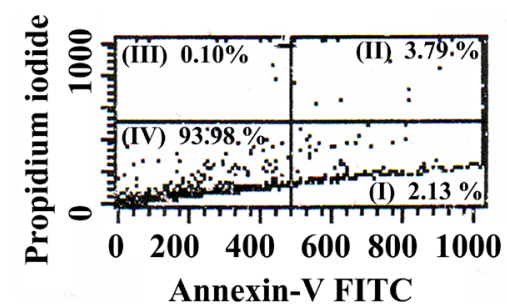

(a)

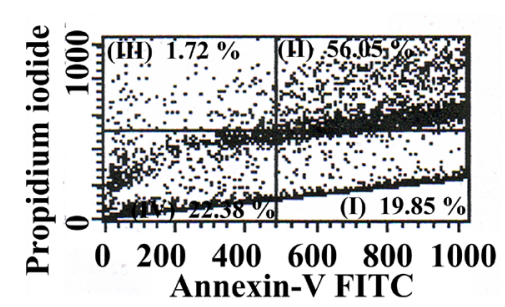

(b)

Figure 1. Representative picture of flow cytometric analysis of (a) untreated A549 cells (b) A549 cells treated with $10 \mathrm{mg} \cdot \mathrm{dw} \cdot \mathrm{mL}^{-1} \mathrm{~S}$. horvatii ssp. macrophylla extract for $24 \mathrm{~h}$. I) Early apoptotic cells (Annexin $\mathrm{V}^{+}, \mathrm{PI}^{-}$); II) Late apoptotic cells (Annexin $\mathrm{V}^{+}, \mathrm{PI}^{+}$); III) Necrotic cells (Annexin $\mathrm{V}^{-}, \mathrm{PI}^{+}$) and IV) Viable cells (Annexin $\mathrm{V}^{-}, \mathrm{PI}^{-}$).

\section{Influence of S. horvatii ssp. macrophylla extract on A549 cells}

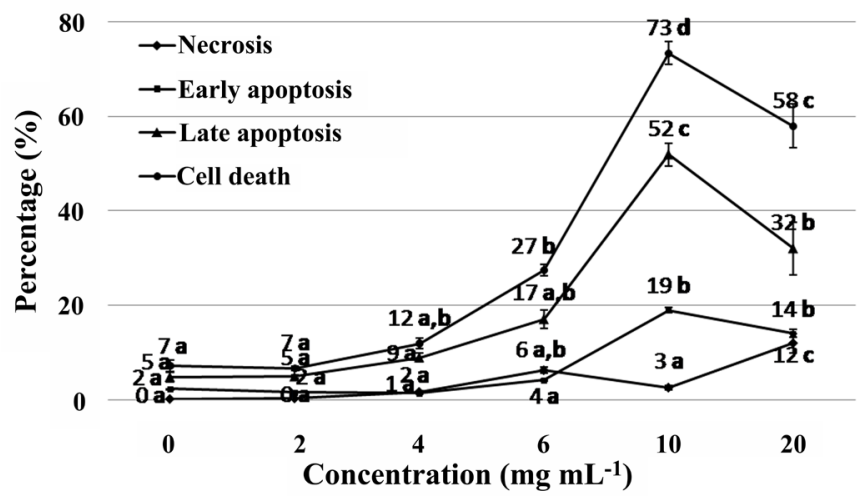

Figure 2. S. horvatii ssp. macrophylla-induced apoptosis/necrosis of A549 cancer cells as measured by flow cytometry. Cells were treated with $0,2,4,6,10$, $20 \mathrm{mg} \cdot \mathrm{dw} \cdot \mathrm{mL}^{-1}$ for $24 \mathrm{~h}$, stained by annexin V/PI. Results of early apoptotic cells, late apoptotic/necrotic cells, necrotic cells and cell death are expressed as percentage of total cells, measured for 10.000 events. For each line the means with the same letter do not present significant difference (Bonferroni $\mathrm{p}>0.05$ ).
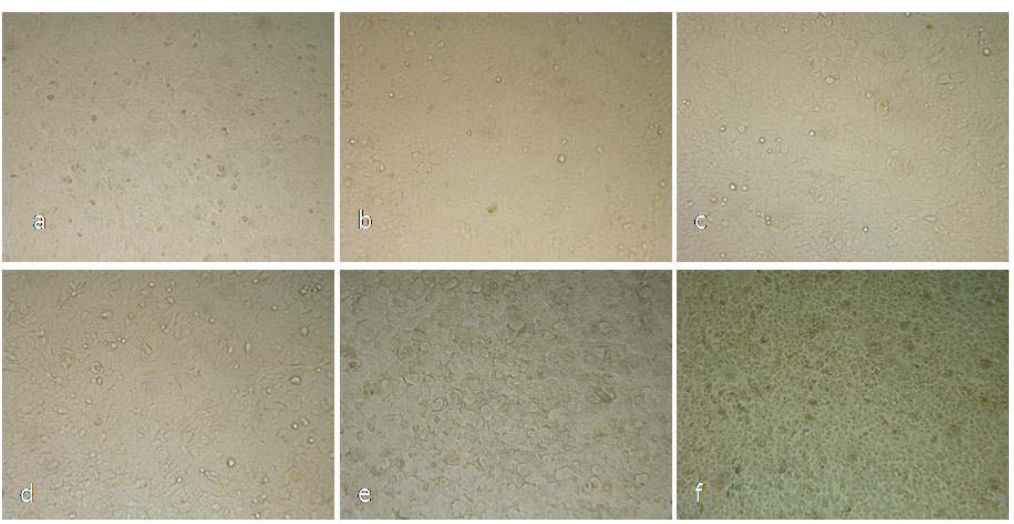

Figure 3. Effect of methanol extract from S. horvatii ssp. macrophylla on cell morphology. Representative pictures were obtained after treatment of confluent A549 cells for $24 \mathrm{~h}$ with various concentrations of the plant extract. (a) Control: $0 \mathrm{mg} \cdot \mathrm{dw} \cdot \mathrm{mL}^{-1}$; (b) $2 \mathrm{mg} \cdot \mathrm{dw} \cdot \mathrm{mL}^{-1}$; (c) $4 \mathrm{mg} \cdot \mathrm{dw} \cdot \mathrm{mL}^{-1}$; (d) $6 \mathrm{mg} \cdot \mathrm{dw} \cdot \mathrm{mL}^{-1}$; (e) 10 $\mathrm{mg} \cdot \mathrm{dw} \cdot \mathrm{mL}^{-1}$; (f) $20 \mathrm{mg} \cdot \mathrm{dw} \cdot \mathrm{mL}^{-1}$. Cells were observed with an inverted microscope (A. Krüss optronic, Germany), at $\times 100$ magnification. 

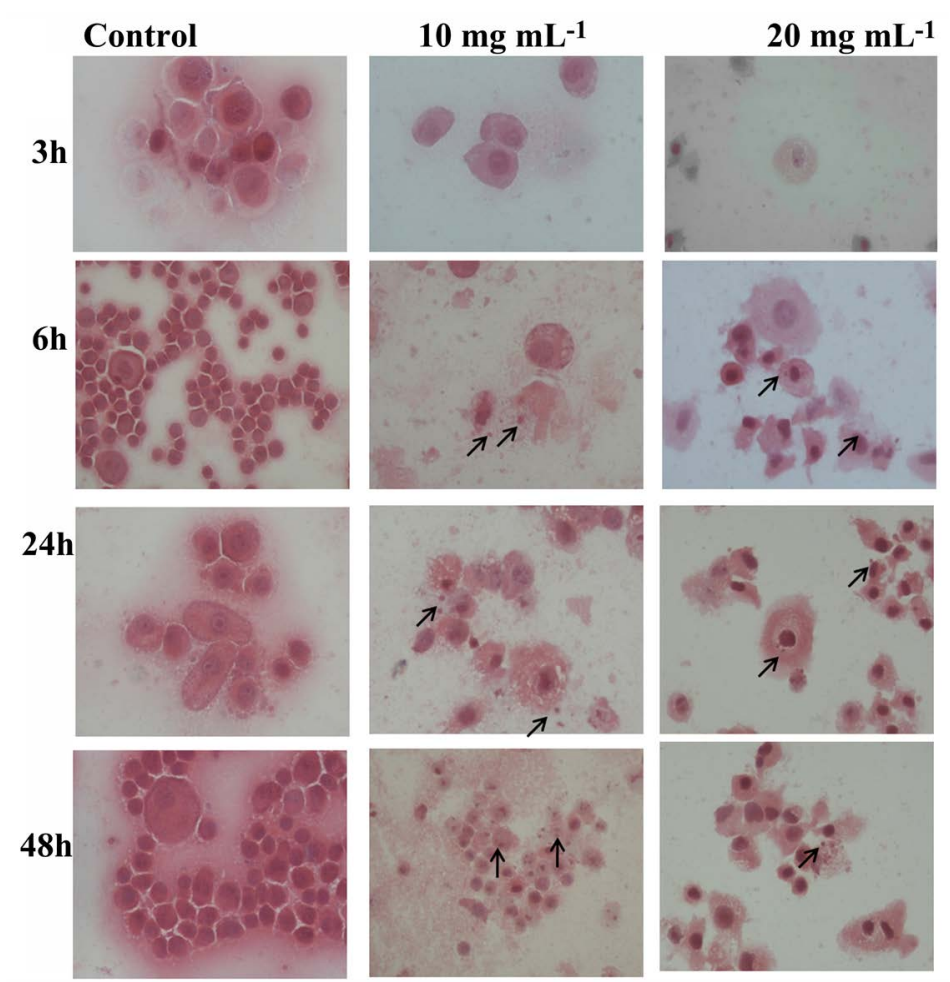

Figure 4. Effect of $S$. horvatii ssp. macrophylla extract on A549 cells in dose- $\left(0,10\right.$ and $\left.20 \mathrm{mg} \cdot \mathrm{dw} \cdot \mathrm{mL}^{-1}\right)$ and time-dependent experiments, for 3, 6, 24, 48 hours. Cells were stained with haematoxyline-eosin and observed with an optical microscope (Nikon eclipse 50i). Representative pictures were obtained from 3 independent experiments at $\times 400$ magnification. Arrows indicate the formation of micronuclei or apoptotic bodies $(\boldsymbol{\lambda})$ and chromatin clumping ( $\mathbf{4})$.

showed characteristics compatible with apoptosis, such as cellular shrinkage, condensed nuclei and cytoplasm (pycnosis), formation of micronuclei and apoptotic bodies. In particular, nuclear and cytoplasmic condensation was an early event, observed as early as $3 \mathrm{~h}$ of incubation, while micronuclei and apoptotic bodies were noticed later (at $6 \mathrm{~h}$ of incubation).

Cells treated for $24 \mathrm{~h}$ with $10 \mathrm{mg} \cdot \mathrm{mL}^{-1}$ of the extract showed, besides increased apoptosis, characteristic morphological changes, such as the presence of foamy cytoplasm with cytoplasmic vacuoles. Moreover, after 48 h, approximately $50 \%$ of the cells exhibited chromatin clumping. Such morphological alterations were not observed in cells treated with higher concentrations $\left(20 \mathrm{mg} \cdot \mathrm{mL}^{-1}\right)$. Although apoptosis was observed in a significant percentage of cells at the highest concentration tested, $\left(20 \mathrm{mg} \cdot \mathrm{mL}^{-1}\right)$, the presence of apoptotic bodies was lower than for the concentration of $10 \mathrm{mg} \cdot \mathrm{mL}^{-1}$.

Nuclear morphology changes were verified using DAPI staining in A549 cells. Apoptotic cells were recognized on the basis of typical features including the presence of condensed, fragmented, and degraded nuclei, which were hallmarks of apoptosis. Nuclei with apoptotic characteristics were observed early, after $3 \mathrm{~h}$ incubation. The presence of herbal fluorescent compounds into the cytoplasm was visible after $24 \mathrm{~h}$ of incubation at the highest concentration and after $48 \mathrm{~h}$ at both concentrations 10 and $20 \mathrm{mg} \cdot \mathrm{mL}^{-1}$.

\subsection{Western Blot Analysis}

Caspase family proteases are key factors in apoptosis. To investigate further the $S$. horvatii ssp. macrophyllainduced apoptosis in A549 cells, the expression of caspase-3 protein involved in apoptosis was examined by western blot analysis. As shown in Figure 5, a reduction in procaspase-3 (32 kDa) levels was observed after 24 $\mathrm{h}$ treatment with $S$. horvatii ssp. macrophylla extract at both concentrations of 10 and $20 \mathrm{mg} \cdot \mathrm{mL}^{-1}$ compared with the control, confirming the activation of caspase- 3 through cleavage of pro-caspase. These results are 


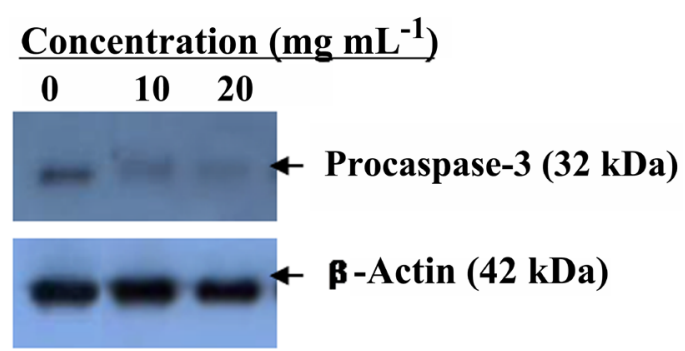

Figure 5. Effect of S. horvatii ssp. macrophylla extract on procaspase-3 levels of A549 cells. The cells were treated with 10 and $20 \mathrm{mg} \cdot \mathrm{mL}^{-1}$ for $24 \mathrm{~h}$. The representative western blot shows the decrease in procaspase- 3 levels with increasing concentrations of the plant extract, using $\beta$-actin as a control of equal loading.

compatible with cell apoptosis.

\section{Discussion}

In the present study we showed that the aromatic plant $S$. horvatii ssp. macrophylla affected the viability of A549 cancer cell line. Flow cytometric analysis showed that different concentrations of the working plant extract solution, used for cell treatment, induced cell death, in the form of apoptosis and necrosis. Morphological evaluation of cells showed apoptotic characteristics, such as nuclear and cytoplasmic condensation, formation of micronuclei and apoptotic bodies, as well as necrotic characteristics, such as oncosis, vacuolization and chromatin clumping in dose and time-dependent manners while the attenuation of procaspase- 3 levels which was observed by immunobloting indicated the pro-apoptotic activity of the extract.

It is well established that one of the early events of apoptosis is the translocation of membrane phosphatidylserine (PS) from the inner side of the plasma membrane to the surface. Annexin V binds preferentially to phosphatidylserine with a high affinity and thus, it can be used to determine apoptosis. During the initial stages of apoptosis the cell membrane remains impermeable for dyes such as propidium iodide (PI). Flow cytometry showed that for cells treated with concentrations of the plant extract higher than $6 \mathrm{mg} \cdot \mathrm{dw} \cdot \mathrm{mL}^{-1}$ for $24 \mathrm{~h}$, a significant increase of Annexin $\mathrm{V}$ staining $\left(\mathrm{A}^{+} / \mathrm{PI}^{-}\right.$or $\mathrm{A}^{+} / \mathrm{PI}^{+}$cells) was observed. These results are in good agreement with the attenuation in procaspase-3 levels observed by immunoblotting, as well as with the morphological evaluation of cells stained with eosin-haematoxylin and DAPI stains, confirming the pro-apoptitic activity of $S$. horvatii ssp. macrophylla extract towards A549 cancer cells. During apoptosis, caspases, enzymes normally present as inactive proenzymes with cysteine proteases activity, are activated through precisely controlled proteolytic cleavage. Procaspase-3 is the inactive form of caspase-3, which is an executioner caspase in apoptosis.

Our results showed an increase in early and late apoptosis up to concentrations of the plant extract 10 $\mathrm{mg} \cdot \mathrm{dw} \cdot \mathrm{mL}^{-1}$, compared with the control cells, without any increase in necrosis. However, morphological examination with inverted microscope revealed that the cells at this concentration displayed morphology of necrosis, with characteristics of oncosis. This phenomenon could be attributed to an interaction of the lipophilic terpenic components of the plant extract with the cell membrane and perturbation of its permeability. However, this hypothesis may not be valid, since at the higher concentration $\left(20 \mathrm{mg} \cdot \mathrm{mL}^{-1}\right)$ this phenomenon of swelling is reduced in parallel with a decline in the percentage of apoptosis and cell death and an increase in necrosis. According to the literature compounds like carvacrol, thymol [20] and thymoquinone [21], components of the active extract, express pro-oxidant or antioxidant activity, depending on the concentration and the cell type. Prooxidant activity and ROS-mediated apoptosis of the plant extract constituents and their antioxidant activity at higher concentrations could explain the induction of apoptosis in cells with necrotic morphology as well as the attenuation of the effect with increasing concentrations.

By combining the information from the flow cytometric analysis and the microscopic observation of cells stained with haematoxylin-eosin and DAPI, it seems that the inadequate cell count observed by flow cytometric analysis on cells treated with $10 \mathrm{mg} \cdot \mathrm{mL}^{-1}$, may be due to the excess of apoptotic bodies in the cell suspension and the increase in viscosity. On the other hand, the normal cell count (events $\mathrm{mL}^{-1}$ ) during the flow cytometric 
analysis at the higher concentration of $20 \mathrm{mg} \cdot \mathrm{mL}^{-1}$, in addition with the condensed nuclei and cytoplasm of A549 cells observed by microscopy may signify that the apoptotic procedure was initiated but not completed. Taking into account the fact that apoptotic process can be completed within 2 - 3 hours [22], the observation of condensed nuclei and cytoplasm after longer than $24 \mathrm{~h}$ exposure and the formation of irregular chromatin clumping could be associated with low ATP levels, switching the cell death pathway from apoptosis to necrosis [23].

To identify the ingredients which promoted apoptosis and necrosis to A549 cancer cells, we performed analysis of different fractions extracted from the plant. From the GC/MS analysis of $\mathrm{MeOH}$ extract it was concluded that $S$. horvatii ssp. macrophylla used in the experiment belonged to carvacrol chemotype. The major portion of the volatile compounds was lost during the preparation of the working plant extract solution, especially during evaporation of the solvent at $40^{\circ} \mathrm{C}$. Interestingly, the procedure was accompanied by a characteristic odor. This assumption was confirmed by DHS/GC/MS analysis which showed that a big portion of volatiles were removed from the plant and recovered in the vapor of DHS at $40^{\circ} \mathrm{C}$. An additional reason for the loss of volatiles is the lipophilicity of essential oil compounds that renders them insoluble to the aqueous environment of the working plant extract solution.

From the composition of different fractions we can assume that the induction of cell death can be attributed to the identified components. In particular, the biological properties of the oxygenated monoterpenes carvacrol, thymol and thymoquinone, present in the working plant extract solution, are well established: Carvacrol possesses antimicrobial [24], insecticidal [25], anti-oxidant [26], anti-inflammatory [27], antimetastatic [28] and pro-apoptotic activities [29] on human cancer cell lines, possibly mediated by ROS [30]. Carvacrol inhibits cell proliferation and affects viability, induces apoptosis and causes concentration-dependent morphological changes on A549 and not to Hep-2 cells [29]. Moreover it is an acetylcholinesterase inhibitor [31].

Thymoquinone has been shown to posses antioxidant, anti-inflammatory and antitumor activity against a broad spectrum of cancer cells. The anticancer effects are mediated through different modes of action, including antiproliferation, apoptosis induction, cell cycle arrest, ROS generation and anti-metastasis/antiangiogenesis [21]. It is suggested that thymoquinone can act synergistically with cisplatine, the most active chemotherapeutic agent both in vivo and in vitro; interestingly, their combination appears to act therapeutically in lung cance [32].

Another minor constituent of the applied extract, tepinene-4-ol, has been found to induce apoptosis in A549 and CL 1-0 human lung adenocarcinoma cells through a mitochondrial-mediated pathway and that apoptosis was p53 dependent [33]. This compound induced caspase-depended apoptosis even in human M 14 melanoma cells. It has been suggested that this effect was mediated by the interaction with the plasma membrane and reorganization of membrane lipids [34].

The side effects of conventional medicines and the development of cell resistance raise the necessity for continuing research on the examination of new compounds. Natural compounds with anticancer properties are of interest because of their great structural diversity and their usual low toxicity. Ingredients with anticancer properties added to food are Generally Recognized as Safe (GRAS). S. horvatii spp. macrophylla, known with the common name "thrumbi", is an aromatic plant used in Greek cuisine for flavouring fish and meet. Taking into account the data presented in this study, it appears that $S$. horvatii spp. macrophylla can be regarded as a candidate for further chemical analysis and investigation for its possible anticancer activity.

\section{Conclusion}

The present study provides evidence for the first time that extract of $S$. horvatii spp. macrophylla, Lamiaceae family, which belongs to carvacrol chemotype, can induce both apoptosis and necrosis in the bronchial epithelial cancer cell line A549. This activity is probably due to highly bioactive compounds, such as carvacrol, thymol and thymoquinone, which could even act synergistically.

\section{Acknowledgements}

The authors would like to thank Dr D. Kletsas, Director in Democritus for his kind remarks. The publication fees have been financed by Teiep research committee.

\section{References}

[1] Dardioti, A., Hanlidou, E., Lanaras, T. and Kokkini, S. (2010) The Essential Oils of the Greek Endemic Satureja hor- 
vatii ssp. macrophylla in Relation to Bioclimate. Chemistry \& Biodiversity, 7, 1968-1977. http://dx.doi.org/10.1002/cbdv.200900181

[2] Vagionas, K., Graikou, K., Ngassapa, O., Runyoro, D. and Chinou, I. (2007) Composition and Antimicrobial Activity of the Essential Oils of Three Satureja Species Growing in Tanzania. Food Chemistry, 103, 319-324. http://dx.doi.org/10.1016/j.foodchem.2006.07.051

[3] Dunkić, V., Bezić, N., Vuko, E. and Cukrov, D. (2010) Antiphytoviral Activity of Satureja montana L. ssp. variegata (Host) P. W. Ball Essential Oil and Phenol Compounds on CMV and TMV. Molecules, 15, 6713-6721. http://dx.doi.org/10.3390/molecules15106713

[4] Radonic, A. and Milos, M. (2003) Chemical Composition and in Vitro Evaluation of Antioxidant Effect of Free Volatile Compounds from Satureja montana L. Free Radical Research, 37, 673-679. http://dx.doi.org/10.1080/1071576031000105643

[5] Ćavar, S., Maksimovica, M., Šolić, M.E., Jerković-Mujkić, A. and Bešta, R. (2008) Chemical Composition and Antioxidant and Antimicrobial Activity of two Satureja Essential Oils. Food Chemistry, 111, 648-653. http://dx.doi.org/10.1016/j.foodchem.2008.04.033

[6] Eminagaoglu, O., Tepe, B., Yumrutas, O., Akpulat, H.A., Daferera, D., Polissiou, M. and Sokmen, A. (2007) The in Vitro Antioxidative Properties of the Essential Oils and Methanol Extracts of Satureja spicigera (K. Koch.) Boiss. and Satureja cuneifolia Ten. Food Chemistry, 100, 339-343. http://dx.doi.org/10.1016/j.foodchem.2005.09.054

[7] Oke, F., Aslim, B., Ozturk, S. and Altundag, S. (2009) Essential Oil Composition, Antimicrobial and Antioxidant Activities of Satureja cuneifolia Ten. Food Chemistry, 112, 874-879. http://dx.doi.org/10.1016/j.foodchem.2008.06.061

[8] Grosso, C., Oliveira, A.C., Mainar, A.M., Urieta, J.S., Barroso, J.G. and Palavra, A.M. (2009) Antioxidant Activities of the Supercritical and Conventional Satureja montana Extracts. Journal of Food Science, 74, C713-C717. http://dx.doi.org/10.1111/j.1750-3841.2009.01376.x

[9] Hajhashemi, V., Ghannadi, A. and Pezeshkian, S.K. (2002) Antinociceptive and Anti-Inflammatory Effects of Satureja hortensis L. Extracts and Essential Oil. Journal of Ethnopharmacology, 82, 83-87. http://dx.doi.org/10.1016/S0378-8741(02)00137-X

[10] Cetojević-Simin, D.D., Canadanović-Brunet, J.M., Bogdanović, G.M., Cetković, G.S., Tumbas, V.T. and Djilas S.M. (2004) Antioxidative and Antiproliferative Effects of Satureja montana L. Extracts. Journal of BUON, 9, 443-449.

[11] de Sousa, A.C., Alviano, D.S., Blank, A.F., Alves, P.B., Alviano, C.S. and Gattass, C.R. (2004) Melissa officinalis L. Essential Oil: Antitumoral and Antioxidant Activities. Journal of Pharmacy and Pharmacology, 56, 677-681. http://dx.doi.org/10.1211/0022357023321

[12] Nematollahi-Mahani, S.N., Rezazadeh-Kermani, M., Mehrabani, M. and Nakhaee, N. (2007) Cytotoxic Effects of Teucrium polium on Some Established Cell Lines. Pharmaceutical Biology, 45, 295-298. http://dx.doi.org/10.1080/13880200701214904

[13] Chinou, I., Liolios, C., Moreau, D. and Roussakis, C. (2007) Cytotoxic Activity of Origanum dictamnus. Fitoterapia, 78, 342-344. http://dx.doi.org/10.1016/j.fitote.2007.02.005

[14] Badisa, R.B., Tzakou, O., Couladis, M. and Pilarinou, E. (2004) Cytotoxic Activities of Salvia of the Labiatae Family. Pharmaceutical Biology, 42, 640-645. http://dx.doi.org/10.1080/13880200490902590

[15] Menichini, F., Conforti, F., Rigano, D., Formisano, C., Piozzi, F. and Senatore, F. (2009) Phytochemical Composition, Anti-Inflammatory and Antitumour Activities of Four Teucrium Essential Oils from Greece. Food Chemistry, 115, 679-686. http://dx.doi.org/10.1016/j.foodchem.2008.12.067

[16] Savini, I., Arnone, R., Catani, M.V. and Avigliano L. (2009) Origanum vulgare Induces Apoptosis in Human Colon Cancer $\mathrm{Caco}_{2}$ Cells. Nutrition and Cancer, 61, 381-389. http://dx.doi.org/10.1080/01635580802582769

[17] Abdel-Massih, R.M., Fares, R., Bazzi, S., El-Chami, N. and Baydoun, E. (2010) The Apoptotic and Anti-Proliferative Activity of Origanum majorana Extracts on Human Leukemic Cell Line. Leukemia Research, 34, 1052-1056. http://dx.doi.org/10.1016/j.leukres.2009.09.018

[18] Xavier, C.P., Lima, C.F., Fernandes-Ferreira, M. and Pereira-Wilson, C. (2009) Salvia fruticosa, Salvia officinalis, and Rosmarinic Acid Induce Apoptosis and Inhibit Proliferation of Human Colorectal Cell Lines: The Role in MAPK/ERK Pathway. Nutrition and Cancer, 61, 564-571. http://dx.doi.org/10.1080/01635580802710733

[19] Ebrahimnezhad Darzi, S. and Amirghofran, Z. (2013) Dichloromethane Fraction of Melissa officinalis Induces Apoptosis by Activation of Intrinsic and Extrinsic Pathways in Human Leukemia Cell Lines. Immunopharmacology and Immunotoxicology, 35, 313-320. http://dx.doi.org/10.3109/08923973.2013.768268

[20] Ozkan, A. and Erdogan, A. (2012). A Comparative Study of the Antioxidant/Prooxidant Effects of Carvacrol and Thymol at Various Concentrations on Membrane and DNA of Parental and Drug Resistant H1299 Cells. Natural Product Communication, 7, 1557-1560. 
[21] Woo, C.C., Kumar, A.P., Sethi, G. and Tan, K.H. (2012) Thymoquinone: Potential Cure for Inflammatory Disorders and Cancer. Biochemical Pharmacology, 83, 443-451. http://dx.doi.org/10.1016/j.bcp.2011.09.029

[22] Elmore, S. (2007) Apoptosis: A Review of Programmed Cell Death. Toxicologic Pathology, 35, 495-516. http://dx.doi.org/10.1080/01926230701320337

[23] Nikoletopoulou, V., Markaki, M., Palikaras, K. and Tavernarakis, N. (2013) Crosstalk between Apoptosis, Necrosis and Autophagy. Biochimica et Biophysica Acta-Molecular Cell Research, 1833, 3448-3459. http://dx.doi.org/10.1016/j.bbamcr.2013.06.001

[24] Veldhuizen, E.J., Tjeerdsma-van Bokhoven, J.L., Zweijtzer, C., Burt, S. and Haagsman, H.P. (2006) Structural Requirements for the Antimicrobial Activity of Carvacrol. Journal of Agricultural and Food Chemistry, 54, 1874-1879. http://dx.doi.org/10.1021/jf052564y

[25] Ahn, Y.J., Lee, S.B., Lee, H.S. and Kim, G.H. (1998) Insecticidal and Acaricidal Activity of Carvacrol and $\beta$-Thujaplicine Derived from Thujopsis dolabrata var. hondai Sawdust. Journal of Chemical Ecology, 24, 81-90. http://dx.doi.org/10.1023/A:1022388829078

[26] Yanishlieva, N.V., Marinovaa, E.M., Gordonb, M.H. and Raneva, V.G. (1999) Antioxidant Activity and Mechanism of Action of Thymol and Carvacrol in Two Lipid Systems. Food Chemistry, 64, 59-66. http://dx.doi.org/10.1016/S0308-8146(98)00086-7

[27] Landa, P., Kokoska, L., Pribylova, M., Vanek, T. and Marsik, P. (2009) In Vitro Anti-Inflammatory Activity of Carvacrol: Inhibitory Effect on COX-2 Catalyzed Prostaglandin E 2 Biosynthesis. Archives of Pharmacal Research, 32, 75-78. http://dx.doi.org/10.1007/s12272-009-1120-6

[28] Arunasree, K.M. (2010) Anti-Proliferative Effects of Carvacrol on a Human Metastatic Breast Cancer Cell Line, MDA-MB 231. Phytomedicine, 17, 581-588. http://dx.doi.org/10.1016/j.phymed.2009.12.008

[29] Koparal, A.T. and Zeytinoglu, M. (2003) Effects of Carvacrol on a Human Non-Small Cell Lung Cancer (NSCLC) Cell Line, A549. Cytotechnology, 43, 149-154. http://dx.doi.org/10.1023/B:CYTO.0000039917.60348.45

[30] Liang, W.Z. and Lu, C.H. (2012) Carvacrol-Induced $\left[\mathrm{Ca}^{2+}\right]_{\mathrm{i}}$ Rise and Apoptosis in Human Glioblastoma Cells. Life Sciences, 90, 703-711. http://dx.doi.org/10.1016/j.lfs.2012.03.027

[31] Jukic, M., Politeo, O., Maksimovic, M., Milos, M. and Milos, M. (2007) In Vitro Acetylcholinesterase Inhibitory Properties of Thymol, Carvacrol and Their Derivatives Thymoquinone and Thymohydroquinone. Phytotherapy Research, 21, 259-261. http://dx.doi.org/10.1002/ptr.2063

[32] Jafri, S.H., Glass, J., Shi, R., Zhang, S., Prince, M. and Kleiner-Hancock, H. (2010). Thymoquinone and Cisplatin as a Therapeutic Combination in Lung Cancer: In Vitro and in Vivo. Journal of Experimental \& Clinical Cancer Research, 29, 87. http://dx.doi.org/10.1186/1756-9966-29-87

[33] Wu, C.S., Chen, Y.J., Chen, J.J., Shieh, J.J., Huang, C.H., Lin, P.S., Chang, G.C., Chang, J.T. and Lin, C.C. (2012) Terpinen-4-ol Induces Apoptosis in Human Nonsmall Cell Lung Cancer in Vitro and in Vivo. Evidence-Based Complementary and Alternative Medicine, 2012, Article ID: 818261. http://dx.doi.org/10.1155/2012/818261

[34] Calcabrini, A., Stringaro, A., Toccacieli, L., Meschini, S., Marra, M., Colone, M., Salvatore, G., Mondello, F., Arancia, G. and Molinari, A. (2004) Terpinen-4-ol, the Main Component of Melaleuca alternifolia (Tea Tree) Oil Inhibits the in Vitro Growth of Human Melanoma Cells. Journal of Investigative Dermatology, 122, 349-360.

http://dx.doi.org/10.1046/j.0022-202X.2004.22236.x 